\title{
Open-field behavior in eight taxa of muroid rodents
}

\author{
DANIEL G. WEBSTER, DENIS J. BAUMGARDNER, and DONALD A. DEWSBURY \\ University of Florida, Gainesville, Florida 32611
}

\begin{abstract}
Open-field behavior was observed in 10-min tests of 10 males of each of eight taxa of muroid rodents. Results parallel those of an earlier study of muroid rodents by Wilson, Vacek, Lanier, and Dewsbury (1976). Considerable variation among species was found for measures of locomotion, boli deposited, and most other behavioral patterns recorded. As in the Wilson et al. (1976) study, animals displayed a strong tendency to seek walls. Correlation coefficients between measures of locomotor-exploratory behavior and number of boli are presented for 20 taxa of muroid rodents; no support is found for a negative correlation between these measures for these taxa.
\end{abstract}

Most studies of open-field behavior have dealt with single species of domesticated rodents or with comparisons of species or strains of domestic rodents (e.g., Harrington, 1972). Although such studies provide valuable data for some purposes, the addition of data on relatively nondomesticated species is necessary if one wishes to seek ecological correlates of these behaviors. Open-field data are available for some species of nondomesticated rodents (e.g., Garten, 1977) and for within-species comparisons of wild-type vs. domesticated rodents of some species (e.g., Hughes, 1978; Smith, 1977), but few studies are available that provide data for comparisons of a number of species under identical conditions (e.g., Glickman \& Hartz, 1964). Wilson, Vacek, Lanier, and Dewsbury (1976) conducted one such study, in which they compared the behavior of 12 species of muroid rodents. The present study was conducted to complement the study of Wilson et al. by providing data on additional species in order to expand the available base of comparative information on rodent open-field behavior.

\section{METHOD}

The subjects for this research were 80 sexually mature ( $\geqslant 90$ days old, or presence of scrotal testes) male muroid rodents. There were 10 animals from each of the following eight taxa: Peromyscus polionotus (old field mice), Peromyscus maniculatus blandus (deer mice), Peromyscus maniculatus bairdi (deer mice), Mus musculus (house mice), Microtus canicaudus (grey-tailed vole), Onychomys leucogaster (Northern grasshopper mice), Rhabdomys pumilio (African striped mice), and Calomys callosus (laucha de campo). The customary abbreviations for genera (e.g., M. canicaudus) will be used; although several genera start with identical letters, species names permit unambiguous identification. All animals were born and raised in this laboratory and maintained on a 16:8 light-dark cycle. Animals were adapted to the test room for at least $24 \mathrm{~h}$ before testing and had continuous access to food and water.

The open field was constructed of plywood painted a flat gray, and measured $101.6 \times 101.6 \times 4.7 \mathrm{~cm}$. The floor was demarcated by painted black lines into 25 squares of equal dimensions, which could be treated as belonging to three classes: squares bounded by two walls $(2 \mathrm{~W})$, one wall $(1 \mathrm{~W})$, or no walls $(0 \mathrm{~W})$. The field was illuminated for testing by a $60-\mathrm{W}$ red light bulb suspended approximately $1.5 \mathrm{~m}$ above the center square.

Animals were tested in the middle of the dark phase of their reversed light-dark cycle. Each animal received a single 10 -min test in the open field. For purposes of data collection, the test was divided into five 2-min periods. Behavioral patterns were recorded with an Esterline Angus operations recorder by one observer while square entries, defined as "both the animal's forepaws in a square," were recorded by the other observer, who activated microswitches connected to a bank of printout counters. Both of these machines remained outside the testing room. The open field was thoroughly washed with pine-scented detergent before each test. Tests were initiated by releasing the animal in a corner square of the open field. Frequency and duration were recorded for 10 behavioral categories: rearing, rearing at wall, freezing, gnawing at open field, scratching at field, jumping, locomotor-exploratory behavior, grooming, head movement, and climbing. A complete definition of these categories has been previously reported (Wilson et al., 1976). Fecal boli were counted at the end of each test. Other animals housed in the testing room provided background masking noise during testing.

\section{RESULTS}

The data from the categorization of behavioral patterns are presented in Table 1. A mean of $99.9 \%$ of the test period was accounted for (range =97.6-101.5). Locomotor-exploratory behavior was the most prevalent pattern for all taxa; gnawing and climbing were the least prevalent patterns for most taxa. Considerable interspecific variation was found for some behavioral patterns. For example, whereas striped mice spent nearly one-third of the time freezing, old field mice spent just $1 \%$; house mice spent 10 times more time rearing than old field mice.

The mean total numbers of squares entered in the 10-min tests for each of the eight taxa are presented. in Table 2. The difference in the total number of squares crossed by different species was statistically significant 
Table 1

Percentage of Time Spent in Each of 10 Behavioral Categories by Eight Taxa

\begin{tabular}{|c|c|c|c|c|c|c|c|c|c|c|}
\hline Taxon & Rear & $\begin{array}{c}\text { Rear } \\
\text { at Wall }\end{array}$ & Freeze & $\begin{array}{l}\text { Gnaw } \\
\text { Field }\end{array}$ & $\begin{array}{c}\text { Scratch } \\
\text { Field }\end{array}$ & Jump & $\begin{array}{l}\text { Loco- } \\
\text { Explore }\end{array}$ & Groom & $\begin{array}{l}\text { Head } \\
\text { Move }\end{array}$ & Climb \\
\hline P. m. bairdi & 1.6 & 9.1 & 16.5 & .5 & 0.0 & 1.6 & 59.1 & 5.3 & 5.0 & 1.2 \\
\hline P. $m$. blandus & 4.2 & 21.5 & 20.4 & 1.0 & .2 & 4.0 & 33.9 & 10.2 & 4.1 & .6 \\
\hline P. polionotus & .9 & 14.0 & 4.8 & .6 & 1.9 & 1.3 & 55.9 & 10.4 & 8.7 & 1.5 \\
\hline M. canicaudus & 1.1 & 6.0 & 22.8 & 1.5 & .8 & .1 & 43.8 & 12.1 & 11.7 & .2 \\
\hline O. leucogaster & 5.9 & 14.0 & 1.1 & .6 & 1.8 & 3.0 & 65.4 & 6.0 & 1.7 & .4 \\
\hline M. musculus & 9.4 & 11.7 & 7.3 & .2 & .9 & 1.8 & 61.0 & 2.5 & 3.8 & 1.3 \\
\hline$R$. pumilio & 4.3 & 5.1 & 30.1 & .2 & .1 & .4 & 46.4 & 2.1 & 11.4 & 0.0 \\
\hline C. callosus & 1.9 & 14.0 & 11.7 & .5 & .3 & .1 & 63.8 & 3.3 & 4.1 & .7 \\
\hline
\end{tabular}

Table 2

Means and Standard Errors for Number of Boli and Total Number of Squares Crossed and Results of Analysis of Variance for Changes as a Function of Period for Eight Taxa

\begin{tabular}{|c|c|c|c|c|c|c|}
\hline \multirow[b]{2}{*}{ Taxon } & \multicolumn{2}{|c|}{ Number of Boli } & \multicolumn{2}{|c|}{ Number of Squares } & \multicolumn{2}{|c|}{ Inferential Statistics on Square Crossings } \\
\hline & Mean & $\mathrm{SE}$ & Mean & $\mathrm{SE}$ & $\mathrm{F}$ (Period) & Significant Comparisons* \\
\hline P. m. bairdi & 3.2 & .5 & 609.3 & 141.2 & $<1$ & \\
\hline P. m. blandus & 6.5 & 1.6 & 334.0 & 76.0 & $2.82 \dagger$ & \\
\hline P. polionotus & 8.4 & 1.8 & 393.4 & 28.3 & $27.37+\dagger$ & $1>2,3,4,5 ; 2>3,4,5 ; 3>4,5$ \\
\hline M. canicaudus & 1.7 & .5 & 279.8 & 70.3 & 1.64 & \\
\hline O. leucogaster & 3.3 & .6 & 688.0 & 39.4 & 2.15 & \\
\hline M. musculus & 2.3 & .8 & 342.5 & 20.7 & $23.29+\dagger$ & $1>2,3,4,5 ; 2>4,5 ; 3>4,5$ \\
\hline R. pumilio & 3.2 & 1.2 & 441.0 & 127.0 & $<1$ & \\
\hline C. callosus & 3.9 & 1.4 & 601.9 & 66.6 & $4.12+\dagger$ & $4>1,2 ; 5>1,2$ \\
\hline
\end{tabular}

${ }^{*} p<.05$ or better.

$t p<.05$.

$\dagger+p<.01$

$[F(7,72)=3.41, \quad p<.003]$, using an analysis of variance. Three significant differences were revealed in individual comparisons using the Newman-Keuls method: $O$. leucogaster entered significantly more squares than $P$. maniculatus blandus, $M$. musculas, or $M$. canicaudus.

Data on changes in the mean number of squares entered as a function of the five successive 2 -min periods are also presented in Table 2 . Using analyses of variance for repeated measures (Winer, 1962), four of the eight taxa studied demonstrated significant differences in mean number of squares crossed as a function of period. Individual comparisons among periods using the Newman-Keuls method for repeated measures revealed a significant decrease over successive periods for $P$. polionotus and $M$. musculus; for $C$. callosus, means for Periods 4 and 5 were significantly greater than those for Periods 1 and 2. Newman-Keuls comparisons for $P$. maniculatus blandus were nonsignificant.

Analyses of variance for repeated measures were also performed for number of square entries as a function of type of square and were followed by individual comparisons with the Newman-Keuls method for repeated measures. Because there were unequal numbers of each type of square available, raw data for these analyses were transformed as follows: The number of entries for each type square $(0 \mathrm{~W}, 1 \mathrm{~W}$, and $2 \mathrm{~W})$ for each animal was divided by the number of each type of square available $(9,12$, and 4 , respectively).
The analyses of variance were significant at the .01 level for all eight taxa except $R$. pumilio, which was significant at the .05 level. The Newman-Keuls method revealed a significantly greater number of entries for $1 \mathrm{~W}$ and $2 \mathrm{~W}$ squares than for $\mathrm{OW}$ squares for all eight taxa.

Partial correlation coefficients for these 80 animals (controlling for the effects of species) showed no significant correlation between the number of fecal boli and either the number of square entries (.02) or the duration of locomotor-exploratory behavior (.01). The correlation between square entries and duration of locomotor-exploratory behavior was significant $(\mathrm{r}=.75, \mathrm{p}<.001)$. Individual correlation coefficients between boli and locomotor-exploratory behavior for the 20 taxa observed in the present study and in the Wilson et al. (1976) study are presented in Table 3. Although many squares by locomotion correlation coefficients were statistically significant, there were few significant correlations with the defecation measure.

\section{DISCUSSION}

A broad base of descriptive data is essential to an understanding of behaviors and their ecological correlates. With the addition of this study to those of Glickman and Hartz (1964) and Wilson et al. (1976), a comparative data base of open-field behavior now exists for 27 taxa of muroid rodents. The existence of such a data base makes searches for correlates 
Table 3

Correlation Coefficients from Comparisons of Three Behavioral Categories for 20 Taxa

\begin{tabular}{|c|c|c|c|}
\hline Taxon & $\begin{array}{c}\text { Squares by } \\
\text { \% Loco- } \\
\text { motion }\end{array}$ & $\begin{array}{l}\text { Squares } \\
\text { by Boli }\end{array}$ & $\begin{array}{l}\% \text { Loco- } \\
\text { motion } \\
\text { by Boli }\end{array}$ \\
\hline P. leucopus & .54 & .20 & $.65^{*}$ \\
\hline P. gossypinus & $.71^{*}$ & -.10 & .03 \\
\hline P. m. blandus & .29 & .12 & .39 \\
\hline P. m. bairdi & $.88 * *$ & -.32 & -.31 \\
\hline P. polionotus & $.78 * *$ & .23 & .09 \\
\hline$P$. eremicus & -.09 & -.43 & .22 \\
\hline M. ochrogaster & .44 & -.06 & -.10 \\
\hline M. montanus & $.76^{*}$ & .17 & -.13 \\
\hline M. pennsylvanicus & $.88 * *$ & .49 & $.64 *$ \\
\hline M. canicaudus & $.93 * *$ & .11 & .12 \\
\hline M. californicus & $.74^{*}$ & -.01 & -.06 \\
\hline B. taylori & .54 & -.04 & -.20 \\
\hline O. phyllotis & $.98 * *$ & -.19 & -.29 \\
\hline M. musculus & .34 & .15 & -.31 \\
\hline O. leucogaster & -.31 & .26 & -.44 \\
\hline R. pumilio & $.91 * *$ & .35 & .21 \\
\hline C. callosus & $.64 *$ & .42 & -.08 \\
\hline S. teguina & $.91 * *$ & .15 & .24 \\
\hline M. tristrami & .51 & -.29 & .07 \\
\hline M. auratus & .59 & .00 & .00 \\
\hline
\end{tabular}

of these behaviors in this group much more practical than previously was the case.

The results of the present study parallel those of the study by Wilson et al. (1976) in many respects. All eight taxa tended to seek walls. Differences were apparent among the taxa with respect to square entries, defecation, and other behavioral patterns. Locomotor-exploratory behavior was the most prevalent behavior pattern, and climbing one of the least prevalent.

Comparison of these taxa in terms of the ecological groupings proposed by Wilson et al. (1976) was not practical since, with the exception of $P$. manculatus blandus and $O$. leucogaster, all taxa are primarily field dwellers. In comparison with the performance of the species included in each of the ecological groupings proposed by Wilson et al., the scores of these taxa appear to be distributed in such a manner as to be uncorrelated with any of the three proposed ecological groups.

No correlation was found, for any of the eight taxa, between either number of boli and total squares entered, or number of boli and percent test duration of locomotorexploratory behavior. These results are consistent with those of Wilson et al. (1976). Inspection of Table 3, where data from 20 taxa are presented, reveals only two significant correlations between measures of locomotor-exploratory behavior and amount of defecation (percent locomotion by boli; $P$. leucopus and $M$. pennsylvanicus); both of these correlations are positive. Although a negative correlation has often been demonstrated between open-field activity and defecation for domesticated rodents (e.g., Hall, 1934, 1936; Walden, 1968; Wilcock \& Broadhurst, 1967) and evidence for a genetic correlation in the same direction has also been provided (DeFries, Gervais, \& Thomas, 1978; Halcomb, Hegmann, \& DeFries, 1975), such a correlation is not apparent for these nondomesticated rodents.

High levels of stereotyped behaviors were exhibited by individuals of some species in this study; P. maniculatus blandus, for example, exhibited a continuous rapid circling of the perimeter of the open field; $P$. maniculatus bairdi exhibited a high level of back flips; $C$. callosus exhibited a stereotyped "windshield-wiper" behavior in which the animal alternately reared back and forth across two squares. Such stereotyped behaviors influence measures of locomotor activity and subsequent correlations between these behaviors and others such as defecation. These correlations will also be affected by differences among observers in the categorization and scoring of stereotyped behaviors, which may, in part, account for the lack of, consistency of such correlations. In addition to stereotyped behaviors, there exist many other factors that may influence open-field measures of locomotion. Henderson (1963) proposed two categories of these factors: subject conditions and testing conditions. Among subject conditions are included such factors as sex, age, and rearing conditions. Testing conditions include such factors as room surroundings, temperature, and observer bias. Even the animals' familiarity with an observer (Morlock, McCormick, \& Meyer, 1971) or the mere presence of an observer (Hughes, 1978) may affect measures of locomotion. Many investigators, in order to control for biases from some of these factors, have resorted to the use of automated open fields. As noted by Hughes (1978), however, most of these apparatus have their own limitations and locomotor scores are often inflated or deflated by the biases of the apparatus. In addition, these apparatus, unless used in conjunction with an observer or camera, permit only a very limited quantification of the behavior of the animal. While it may not be possible to control for the effects of all of the factors mentioned, their influence on interpretation of crossspecies comparisons may be minimized, or at least made more interpretable, by collecting data in a consistent fashion across species and studies as exemplified by the present study.

\section{REFERENCES}

DeFries, J. C., Gervais, M. C., \& Thomas, E. A. Response to 30 generations of selection for open-field activity in laboratory mice. Behavior Genetics, 1978, 8, 3-13.

GARTEN, C. T. Relationships between exploratory behavior and genic heterozygosity in the old field mouse. Animal Behaviour, 1977, 25, 328-332.

Glickman, S. E., \& Hartz, K. E. Exploratory behavior in several species of rodents. Journal of Comparative and Physiological Psychology, 1964, 58, 101-104.

Halcomb, R. A., Hegmann, J. P., \& DeFries, J. C. Open-field behavior in mice: A diallel analysis of selected lines. Behavior Genetics, 1975, 5, 217-231.

HALL, C. S. Emotional behavior in the rat. I. Defecation and urination as measures of individual differences in emotionality. Journal of Comparative Psychology, 1934, 18, 385-403.

HALl, C. S. Emotional behavior in the rat. III. The relationship between emotionality and ambulatory behavior. Journal of Comparative Psychology, 1936, 22, 345-352.

HARRINGTON, G. M. Strain differences in open-field behavior of the rat. Psychonomic Science, 1972, 27, 51-53.

Henderson, N. D. Methodological problems in measuring ambulation in the open field. Psychological Reports, 1963, 13, 907-912.

Hughes, C. W. Observer influence on automated open-field activity. Physiology \& Behavior, 1978, 20, 481-485.

Morlock, G. W., McCormick, C. E., \& Meyer, M. E. The effect of a stranger's presence on the exploratory behavior of rats. Psychonomic Science, 1971, 22, 3-4.

SMITH, R. H. Open-field freezing as a stable parameter of wildness in Mus musculus. Behavioral Biology, 1978, 23, 67-74.

WALDEN, A. M. Studies of exploratory behavior in the albino rat. Psychological Reports, 1968, 22, 483-499.

WILCOCK, J., \& BROADHURST, P. L. Strain differences in emotionality: Open-field and conditioned avoidance behavior in the rat. Journal of Comparative and Physiological Psychology, 1967, 63, 335-338.

Wilson, R. C., Vacek, T., Lanier, D. L., \& Dewsbury, D. A. Open-field behavior in muroid rodents. Behavioral Biology, 1976, 17, 495-506.

WINER, B. J. Statistical principles in experimental design. New York: McGraw-Hill, 1962.

(Received for publication November 20, 1978.) 